Corrigendum

\title{
rol genes of Agrobacterium rhizogenes cucumopine strain: sequence, effects and pattern of expression
}

\author{
G. Serino ${ }^{1}$, D. Clerot ${ }^{2}$, J. Brevet ${ }^{2}$, P. Costantino ${ }^{3}$ and M. Cardarelli ${ }^{1, *}$ \\ ${ }^{I}$ Centro per lo Studio degli Acidi Nucleici, CNR, Roma, Italy (*author for correspondence); ${ }^{2}$ Institut des \\ Sciences Végétales, CNRS, Gyf Sur Yvette, France; ${ }^{3}$ Dip. Genetica e Biologia Molecolare, Università \\ 'La Sapienza', Roma, Italy
}

Plant Molecular Biology 26: 415-422, 1994.

In the acknowledgements section of the above-mentioned paper, we neglected to mention the paper number of the subproject of Special Project RAISA. We herewith print the amended version of the Acknowledgements:

\section{Acknowledgements}

This work was partially supported by an EEC Project of Technological Priority Contract to the Consorzio Interuniversitario Nazionale per la Biologia Molecolare delle Piante, by the Fondazione Istituto Pasteur-Cenci Bolognetti by National Research Council of Italy, Special Project RAISA, subproject 2, paper no. 1913, and by CNRS and EEC/BRIDGE to J.B. 